Bagrat H. Yerznkyan, Doctor of Economic Sciences, Prof., Chief Researcher, Head of Lab., CEMI RAS, Moscow, Russia, lvova1955@mail.ru, yerz@cemi.rssi.ru

Karine A. Fontana, Candidate of Economic Sciences, Senior Researcher, CEMI RAS, Moscow, Russia, fontana@mail.ru

\title{
WATER RESOURCES AND THE PROBLEM OF EXTERNALITIES
}

\begin{abstract}
When managing water resources as an integral part of urban management, unforeseen situations, particularly related to the occurrence of side effects (externalities), often arise. Such effects aggravate the environmental situation and exacerbate global challenges to humanity in the field of water supply and rational use of water resources, including through the introduction of alternative methods of water supply. Providing water to the parties involved and their use by them can lead to externalities - both positive and negative. Problems usually arise in the situation with negative externalities, the elimination or mitigation of which necessitates technological and institutional solutions. The first solutions concern technical methods, such as wastewater treatment, for example, and their repeated or better regular reuse, as it is practiced in the circular economy, the second ones affect institutional solutions that can be divided into three types from a theoretical and methodological point of view. These include: 1) government intervention (practiced in a situation of «market failures»); 2) a Coasen solution (involving market contracting between producers and consumers of negative externalities); 3 ) a hybrid way of problem solving (combining the market efforts of the parties involved and non-market activities of organizations interested in the public good). Keywords: water resources, technological methods, positive and negative externalities, institutional solutions, government intervention, Coase theorem, hybrid solutions, circular economy. JEL Classification: B52, D23, P48, Q53.
\end{abstract}

\section{INTRODUCTION}

In conditions of increasing water stress, one of the important directions of water policy is to achieve the sustainability of the functioning of the urban water sector and to develop measures to reduce the existing and prevent the predicted pressure on water resources, on one hand, and ensure population's continuous access to high-quality water, on the other.

Effective water resource management involves inter alia aligning strategic decisions on them with decisions in other sectors to avoid potential conflicts in city development strategies, to minimize environmental damage within and outside the city, to ensure social justice and economic efficiency, and to ensure reliable water supply to the city.

The relative scarcity of water resources makes it necessary to protect them by both encouraging their effective use and reducing pressure on the water environment through water reuse, and by seeking the ways for minimizing the negative side effects (externalities).

As it is well known externalities may be either positive (education, language comminication) or negative (pollution). As to water resources, one of the important directions of their policy is to provide the sustainability of water resources, development of measures to reduce existing and prevention the projected pressure on them to achieve a satisfactory state 
of natural water resources as well as ensuring continuous access of population to high-quality water. Positive outcomes when using water resources emerge frequently in a situation, say, of automatic irrigation systems (AIS) functioning in the urban and/or municipal areas, although they may be turned in the opposite being polluded (as in case of urban wastewater).

Ways of the solving the problem of externalities, bearing in mind rather negative ones, can de divided into technological and institutional ways. As for the latter, we stems from the methodology of institutional pluralism, which as opposed to institutional monism deals with more than one institutional form or way of realization of economic functioning. It should be underlined that theoretical-methodological demarcation between institutional monism and institutional has as well a crucial practical significance.

So, there is a certain number of the institutional ways of solving the problem of externalities (taxation, regulation, direct intervention, voluntary negotiation, property rights, merges, incentives mechanism design, etc.).

However, two approaches can be underlined - government intervention (because of impossibility of market forces to solve the problem) and private way of problem's solving (stems from the possibility, according to well-known Coase theorem, of the producer and recipient of externalities to come to the result through market transaction). Both of them may theoretically result in Pareto optimum outcomes, but may lead to different income distributions. A kind of another approach, based on relational contracting and regarded as a modification or hybridization of the first two, is presented in (Yerznkyan, 2010; 2012). In the terms of transactions, the government intervention can be associated, speaking in the John Commons language (1934), with rationing transaction, Ronald Coase traditional solution - with market transaction, and the third approach - with managerial transaction (Yerznkyan, 2012, p. 74).

In this article, we try to pay attention to the such negative externality as pollution and its solution bearing in mind that wastewater must be seen not as a waste, from which you want to get rid of, but as a resource, which may be an important element in the sustainable management of water resources and become an important lever in solving freshwater shortages, mitigate the effects of climate change, have beneficial effects on the environment (Fontana, Fontana, 2016).

\section{Technological Solution of Water Pollution}

Water resources and what are connected with them, say AIS, demonstrate a significant variety of specificities meaning what goods they are.

By AIS - automatic irrigation systems - we mean systems that are an engineering complex (engineering equipment with varying degrees of automation - from a simple timer to remote control using specially developed information technologies, IT, for such systems), designed to supply water to plants in conditions of limited rainfalls and providing for an accurately calculated volume of water for irrigation each kind of plants (water consumption is calculated on the basis of the evapotranspiration coefficient). 
As to RW - reuse of water - it means the use of water, coming from treated urban wastewater (domestic wastewater or a mixture of domestic graywater and industrial wastewater, located within city borders and having a common collection system) of a certain quality, intended for it further use in limited applications taking into account legislation and potential risks to public health and to the environment.

Technologically, the logical development of the reuse (possibly, one-time) use of water is the formation of a circular (multiple) economy - a special type of economy based on the use of renewable resources and which is opposite to a traditional, linear economy based on the creation, use, and disposal of them.

Let us now considered what goods they are. In their economic essence, AIS are private goods, the consumers of which can be representatives of business, government, society both inside and outside the city. Policy makers and local authorities responsible for urban economy (UE) can use AISs to produce social (collective, locally public) goods, such as urban green landscapes. In this understanding, AIS, being private goods, can act as factors in the production of social goods.

Speaking about a technological solution to the problem of water pollution, it should be noted the possibility of belonging of the proposed solutions to various technological structures. Particularly acute is the choice of an adequate solution in a situation with innovative ways to solve the problem of re-meritorization of water resources, i.e. giving them as a result of purification inherent to them by the definition their meritorial qualities. Let us recall that by merit goods we mean such goods whose demand from economic agents does not coincide with the normative principles of society (Musgrave, 1987).

Thus, in (Yerznkyan, Fontana, 2018) it is shown the significance of innovative ways of the use of water resources and is underlined that they, being one of the main resources necessary for human life, are capable, when used correctly, of becoming one of the key factors in the sustainable development of the socio-economic system, in particular, urban economy. Such use implies a reliance on innovation and digital technology, as well as effective management based on the opportunities provided by the circular economy.

\section{InStitutional Solutions of WATER Pollution}

The basic concept of wastewater reuse was formulated by UN Economic and Social Council in 1958, under which the water of high quality shall not, unless it has in abundance, to be used for the purposes that allow use of water of lower quality.

Generally speaking, a lack of standard institutional solutions including the uniform global guidelines and rules governing the reuse of wastewater with technological methods and generally accepted levels of wastewater treatment, based on the further use in specific applications (including the possibility to not ignore specific cultural differencies and adapt to local conditions) is a significant deterrent to the expansion of water reuse practices (Yerznkyan, Fontana, 2019). 
In Russia, the rationality of water consumption is arrived at by the decline of losses of water at transporting, reduction of specific consumption of water in technological processes, on service-utility needs, and the last is arrived at by expansion of the use of the circulating and repeatedly-successive water systems, wastewater is used mainly in industry or thrown down in natural reservoirs (Yerznkyan, Fontana, 2018).

\subsection{Government Intervention / Regulation}

As teaches us traditional university course of economics, a pollution as an example of the negative externality leads to a market failure, and to solve this emerged problem one needs to appeal to government. As it is well known, the recipients of negative externalities, suffering from external costs, wish them to be reduced or completely vanished at. As a rule, they appeal to the government so that it, by virtue of possessing legitimate authority to pressure the producers of negative externalities, would restore justice and redistribute them completely or in part - in their own direction.

There are some regulating mechanisms to solve the problem: (i) a Pigouvian tax (i.e. a special tax that is often levied on companies that pollute the environment or create excess social costs); (ii) a technical mechanism can be realized through the purchase and implementation of treatment facilities or replacement of environmentally unacceptable equipment and / or technology; (iii) an economical mechanism can be realized through [the threat of using] penalties, forcing the company to resort to technical means of solving the problem; (iv) legal intervention aimed at ameliorating the problem (it may include direct regulation by restricting permissible behavior; (v) injunction (a potential victim can enlist the power of the state to force a potential injurer to take steps to prevent harm); (vi) corrective tax (in Pigou tradition); (vii) financial incentives (society can make use of them to induce injurers to reduce harmful externalities), and so on (Yerznkyan, 2012, p. 75).

The effectiveness of solving the problem depends on the strength of government. When it is weak, the beneficiaries will be the producers of negative externalities. Although the effectiveness of the government in contemporary Russia is not high, it is difficult to find an alternative to the government intervention, which includes regulative, legislative and other institutional forms of the problem solving. In this regard, we recall that many problems of the Russian economy arose directly or indirectly due to the fact that the state did not play its proper role, including the role of the market relations' organizer.

\subsection{Coase's Market Bargaining}

There are some versions or definitions of the Ronald Coase considerations (1960) and what lately George Stigler called "Coase Theorem". Here is one the definitions:

"If (a) property rights are well-defined, (b) transactions costs are trivial, and (c) wealth effects can be ignored, then externalities are internalized through the selfinterested negotiations of the parties involved, resulting in the same allocation of productive 
resources regardless of who possesses the property rights or liabilities so long as these rights are well specified" (Mitchell, Munger, 1991, p. 532).

According to Coase Theorem, as soon as the powers are in the countries with common law of the market subject of bargaining, then - under certain conditions - the producer and consumer of negative externalities can solve the problem without resorting to a third party the government. It means that if trade concerning externalities is possible and if there are no transaction costs, bargaining will lead to an efficient outcome regardless of the initial allocation of property rights. It is of great importance that the socially efficient level of pollution is by definition a Pareto optimum. If an outcome is not a Pareto optimum, it could be improved in the process of negotiations between counteragents involved in the bargaining transaction.

And although in this case the government is not a player directly involved in the game, "it may be (even more so, in fact, it should - in a situation of formal and legal transactions) the guarantor of the fulfillment of the market contract" (Yerznkyan, 2012, p. 77).

In (Varian, 1987), such a bargaining according to Coase theorem is illustrated graphically "on the Edgeworth box - a convenient analytical tool of relations between market parties with the help of indifference curves, which allows in visual form to present the process of contracting individuals entering into a mutually beneficial, Pareto-efficient exchange of their goods" (Yerznkyan, 2012, p. 78).

\subsection{Relational Contracting}

In the case, when the producer and consumer of negative externalities are stakeholders (i.e. players related in some sense to activity in question), not impersonal contracting parties, realization of classic contract is, strictly speaking, impossible. To be more precise, such a contract between personalized parties will not be, by definition, a market one. This kind of interaction is appropriate to describe in the language of relational contracting.

What is the effectiveness of the implementation of managerial transaction? In modern Russia, the reality is that because of the immaturity of civil society, de facto authority is on the side of corporations. It is reasonable to wonder why then corporations prefer to chose relational (if market bargaining is impossible) contracting and to ignore government intervention. The answer is that this method is economically more advantageous to the same and more attractive to a broader point of view - public opinion, environmental agreements, preservation / enhancement of reputation, etc. (Yerznkyan, 2012, p. 79).

The realization of the relational contracting depends largely on the characteristics of ways of doing business - formally or informally, legally or illegally, following written or unwritten institutions and so on. One of the popular informal business practices in Russia business 'po ponyatiyam' - which can be understood as a specific kind of relational contracting, may be explained from either synchronic (high value of transaction costs of interaction giving rise to a lock-in effect) or diachronic (historical legacy in combination with weak legal system shaping an effect of path-dependency) perspective. 
As to these two effects, let us underline that the lock-in effect means that "once reached, a solution is difficult to exit from" and the path-dependance effect - that "the consequents of small events and chance circumstances can determine solutions that, once they prevail, lead one to a particular path" (North, 1990, p. 94).

By its institutional form the situation of relational contracting is fundamentally different from those considered earlier, which were dyadic from the agency perspective. In the first case we deal with the government and company as the pollution producer, in the second case - with the company and society/community involved in the problem's solution. In the last case a significante role plays the third party, however not as a contract enforcer but as a 'gate-keeper', and this role can really be played by the state/ government. The notion 'gatekeeper' was offered by Anton Oleinik (see, e.g., 2007, 2011) for explaining a possible transition from a dyadic relationship between two counterparties (say, A and B) to a triad (A, B and C) relationship. By 'gate-keeper' it is understood that the third party can regulate access to the field and make it conditional upon acceptance of a particular institution. There is some connotation between this statement and the three forms or general patterns of exchange of Douglas North: personalized exchange, impersonal exchange without third party enforcement, and impersonal exchange with third party enforcement (North, 1990, pp. 34-35).

In addition, we underline that the role of the third party (as gate-keeper, not enforcer) in the Russian practice of the externalities problem solving, can be played only the state (centralized or decentralized government).

Graphically, this case of contracting can be illustrated on the modified form of Edgeworth box by offering a version of Coase theorem based at the fuzzy concepts, "given that decision-makers are often unable to articulate not only their requirements, but also their own preferences, not to mention the difficulties of predicting the preferences of their counterparts" (Yerznkyan, 2012, p. 85).

\section{CONClusion}

The provision of water resources and their use for one purpose or another is usually accompanied by external externalities - positive and / or negative. The former contribute to the sustainable development of, in particular, "smart cities", while the latter create problems that need to be solved. Generally, such solutions have two dimensions - technological and institutional.

Unfortunately, in the context of growing environmental problems around the world and aggravation of global challenges for humanity in the field of water supply, Russia still does not pay enough attention to the issues of the rational use of water resources, in particular in the urban economy, the search for alternative ways to supply water (for example, treated wastewater) and water saving through a wider use of automatic irrigation systems.

In this article, several institutional ways for solving the problem of negative externalities - government regulation, Coasean internalized solution, and relational contracting have been presented. We have compared these three institutional approaches with three types 
of transaction (distributional/rationing, exchange/bargaining, and a kind of managerial, accordingly) and have emphasized that their merits are not uniform and need to be assessed with both the formal institutional rules and the informal institutional norms of real practice, especially in nowadays Russia.

Methodogically, the three institutional alternatives regarded in the article with the three corresponding types of transactions are based on the idea of power as a force: i) possibility of the rationing transaction can be explained by the state power to take enforcement of fair from its point of view options of redistribution of negative externalitis; ii) possibiliy of market solution or bargaining transaction is based on the internalization of enforcement function by counterparts who have enough force to implement this contractual function; iii) possibility of the managerial transaction is based on the contracting force to realizing the relational contracting.

In conclusion, it should be mentioned that in order to achieve positive results in the rational and efficient use and reuse of water resources, the uninterrupted supply of clean water to the population, it is necessary a systemic measures including a set of interrelated ways implemented jointly by state authorities and local self-government, private business, the financial sector, and scientific organizations.

\section{REFERENCES}

1. Coase R.H. (1960). The Problem of Social Cost // Journal of Law and Economics, no. 3, pp. 1-44.

2. Fontana K.A., Fontana C. (2016). Wastewater Use: A New Opportunity for the Green Economy. General overvie // Actual Problems of Humanitarian and Natural Sciences, no. 3, March, part II, pp. 8-11 (in Russ.).

3. Mitchell W.C., Munger M.C. (1991). Economic Models of Interest Groups: An Introductory Survey // American Journal of Political Science, vol. 35, no. 2, May, pp. 512-546.

4. Musgrave R.A. (1987). Merit Goods. In: Eatwell J., Milgate M., Newman P. (eds.). The New Palgrave: A Dictionary of Economics. London, Basingstoke Macmillan, 1987. P. 452-453.

5. North D.C. (1990). Institutions, Institutional Change and Economic Performance. Cambridge, Cambridge University Press.

6. Oleinik A. (2007). Minimizing Missed Opportunities: A New Model of Choice? // Journal of Economic Issues, vol. 41, no 2, pp. 547-556.

7. Oleinik A. (2011). Market as a Weapon: Domination by Virtue of a Constellation of Interests // Forum for Social Economics, vol. 40, no 2, pp. 157-177.

8. Varian H.R. (1987). Intermediate Microeconomics: A Modern Approach. N.Y.: L.: Norton.

9. Yerznkyan B.H. (2010). Fuzzy Version of Coase Theorem: Raison d'etre and Principles of Preferences // Vestnik universiteta (Bulletin of the State University of Management), no. 2, pp. 37-44 (in Russ.).

10. Yerznkyan B.H. (2012). Pluralistic Institutional Solutions of the Problem of Externalities // Montenegrin Journal of Economics, vol. 8, no. 2, special issue, pp. 73-86.

11. Yerznkyan B.H., Fontana K.A. (2018). Institutional Aspects of the Circular Economy's Development in the Sphere of Water Supply // Vestnik CEMI RAN (Bulletin of the CEMI RAS), issue 1, [el. resuorce], pp. 37-44 (in Russ.). URL: http://cemi.jes.su/s111111110000079-9-1. DOI: 10.18254/S0000079-9-1

12. Yerznkyan B.H., Fontana K.A. (2019). Water Reuse and Its Regulation in Russia and Abroad // Materials of the International Conference "Scientific research of the SCO countries: synergy and integration" - Reports in English (July 12, 2019. Beijing, PRC). P.16-23. DOI: 10.34660/INF.2019.12.33342. 


\section{Ерзнкян Б.А., Фонтана К.А. ВОДНЫЕ РЕСУРСЫ И ПРОБЛЕМА ЭКСТЕРНАЛИЙ}

При управлении водными ресурсами как составной частью управления городским хозяйством нередко возникают непредвиденные ситуации, в частности связанные с возникновением побочных эффектов. Такие эффекты усугубляют экологическую обстановку и обостряют глобальные вызовы человечеству в сфере водообеспечения и разумного использования водных ресурсов, в т.ч. за счет внедрения альтернативных способов водоснабжения. Обеспечение заинтересованных сторон водными ресурсами и их использование ими может приводить к экстерналиям (побочным эффектам) - как положительным, так и отрицательным. Проблемы обычно возникают в ситуациях с отрицательными побочными эффектами, устранение или смягчение которых вызывает необходимость в технологических и институциональных решениях. Первые касаются технических способов, таких как очищение сточных вод, к примеру, и их повторное или лучше многократное использование, как это практикуется в циркулярной экономике, вторые затрагивают институциональные способы решения проблемы, которые можно с теоретико-методологической точки зрения подразделить на три типа. К ним относятся: 1) государственное вмешательство (практикуемое в ситуации «провалов рынка»); 2) коузово решение (предполагающее рыночную контрактацию между производителями и потребителями негативных экстерналий); 3) гибридный способ решения (сочетающий рыночные усилия вовлеченных сторон и нерыночную деятельность заинтересованных в общественном благе организаций).

Ключевые слова: водные ресурсы, технологические способы, положительные и отрицательные экстерналии, институциональные решения, государственное вмешательство, теорема Коуза, гибридные решения, циркулярная экономика.

JEL классификаичи: B52, D23, P48, Q53. 